\title{
A Comparative analysis of
} information seeking behaviour of Canadian and international secondary school graduates entering a university

\author{
Jamshid Beheshti, Joan Bartlett, Anna Couch, Cynthia Kumah
}

School of Information Studies, McGill University, Canada

\section{Introduction}

he importance of acquiring information literacy (IL) knowledge and skills in high schools
as a prerequisite to entering colleges and universities has been well-documented in the literature (e.g., Cahoy, 2002; Fitzgerald, 2004; Saunders, Severyn, \& Caron, 2017). This paper investigates the IL knowledge of Canadian and international high school graduates, as they enter a university in Canada. More specifically, the focus is on information seeking behaviour (ISB), part of the Access and Evaluation stages of the IL spectrum (Sparks, Katz, \& Beile, 2016).

\section{Statement of Research Problem}

The IL competency levels of students, both at the secondary and post-secondary levels, have been studied for more than 30 years (Pinto, Cordon, \& Gómez Díaz, 2010); results suggest that while students may be tech-savvy, they lack certain information competencies (e.g., Conde, Migueláñez, Molina, Abad, \& Riaza, 2011; Herring, 2011; Kovalik, Yutzey, \& Piazza, 2012). To date, however, no research has compared Canadian and international students on Access and Evaluation: what resources they access, their perceptions regarding the credibility of these resources (Hogan, \& Varnhagen, 2012; Ginsca, Popescu, \& Lupu, 2015), and the factors used to determine credibility. 


\section{Literature Review}

Over the last few decades, many IL standards and guidelines have been proposed (e.g., Bundy, 2004; OECD, 2013; UNESCO, 2013; ACRL 2015; AASL, 2017). But, adherence to these standards by various countries remains unclear, as are the IL skills of high school graduates, and their ability to manage the academic demands of the postsecondary education (Gross \& Latham, 2012; Detlor, Julien, Willson, \& Serenko, 2011). In addition, due to potential differences in secondary education systems (Hanushek \& Luque, 2003), as well as cultural variances, the ISB and IL skills may vary significantly among students from different regions of the world (Liu \& Winn, 2009).

Several information literacy tests have been developed to assess the knowledge and skills of students (e.g., Project SAILS), the majority of which are based on and informed by traditional IL standards (Sparks, Katz, \& Beile, 2016). Others have proposed scales for self-reporting (e.g., Serap, Kurbanoglu, Akkoyunlu,, \& Umay, 2006). The Metaliteracy model proposed by Mackey \& Jacobson $(2011,2014)$ postulates that IL should be contextualized within the new digital environment and incorporates such factors as collaboration and information sharing. The Metaliteracy model is used as a framework for this research.

\section{Methodology}

As part of a large-scale project, data were collected using a questionnaire survey on the ISB and IL of undergraduate students in a tier one university in Canada. Questions were based on previous literature (Kim \& Sin, 2016), IL instructions offered by the University, and three focus groups (undergraduate students and library staff), and were divided into five broad categories, each with several five-point Likert scale sub-questions:

1. Information resources and use

2. Credibility of information resources

3. Factors that determine credibility

4. Information access and search

5. IL instruction 
The survey was emailed to 22,900 undergraduate students in October 2017, with a response rate of $15.6 \%$ usable questionnaires. Internal reliability testing showed Cronbach's alpha (Krippendorff, 1980) ranging from 0.884 to 0.992.

The data were extracted for first-year undergraduate students: 18 years old, enrolled full-time in U0 (no previous college education) $(\mathrm{n}=378)$. For comparison, data were divided into two groups: Canadian citizens/permanent residents $(n=212)$, and international students $(n=76) .{ }^{1}$ The international group includes: 59\% Chinese, 7\% Turkish, 7\% Arabic, 5\% Spanish, and less than $3 \%$ each, Japanese, Korean, Iranian, Portuguese, and Vietnamese students among others.

\section{Findings}

Figure 1 shows the mean scores of the five-point scale questions on information resources and use. Both groups indicated that their peers are the most utilized information resource. However, t-tests ${ }^{2}$ show significant differences between Canadian and international students in their information behaviour (Table 1). For academic information, international students seem to rely more on government and university websites, social media, wikis, and blogs and forums than their Canadian counterparts.

Although both groups recognize the credibility of experts (e.g., professors, teaching assistants), and government and university websites, their mean scores are significantly different for scholarly books and journals (Figure 2). International students also view social media, wikis, blogs and forums, and well-known websites significantly more credible than their Canadian counterparts.

\footnotetext{
${ }^{1}$ The vast majority of English-speaking international students are from the United States, which has a relatively similar education system as in Canada, and therefore international students whose first language is English are excluded from data analysis.

${ }^{2}$ Due to multiple t-tests, Bonferroni correction (Armstrong, 2014) was applied for each set of questions, and hence these are the minimum number of significant differences.
}

International Association of School Librarianship

https://www.iasl-online.org/ 
The responses show significant differences between groups in their consideration of the following factors in determining credibility: information matching other sources, currency, quality of language, and being among the top five results in Google searches (Figure 3).

Figure 4 shows the mean scores for questions on tools used most often to access academic information. Interestingly, students from both groups rely on Google more than any other tool. Even YouTube is used more frequently than Google Scholar by both Canadian and international students.

A minority of students had received IL instruction (library instruction, citation management, database searching) (Table 2), but no significant differences were detected between the two groups. Since the survey was conducted during the first few weeks of the academic year, and no IL instruction is offered over the summer, this instruction would have taken place prior to entering the university.

The overall correlation results (Table 3) show that formal library instructions and database searching instructions have a positive effect on IL knowledge and skills. It is very likely that students received their formal library instructions in their high schools.

\section{Discussion}

The overall picture that emerges from the findings is:

- Access

- Both Canadian and international students view their peers and colleagues as an important resource for academic information. This finding is aligned with one of the elements of the Metaliteracy model, Collaboration, and corroborates recent studies in this area (e.g., Beheshti \& Large, 2013), and on the topic of peers as social capital (Ellison, Steinfield, \& Lampe, 2007). The international students, however, place more emphasis on social media and wikis for their required information, which may be as a result of the heavy reliance on social media for academic communication within some far east institutions (Chu, Reynolds, Tavares, Notari, \& Lee, 2017). 
○ Both Canadian and international students rely significantly on Google to access academic information. Both groups also use YouTube fairly considerably to obtain information, perhaps due to its use in the classrooms regardless of geographical and cultural divisions (Jung \& Lee, 2015). Many of the incoming students are completely unaware of essential academic tools such as EBSCO, Scopus, and Web of Science (43\%, 45\%, $42 \%$ respectively).

- Evaluation

○ Evaluation was assessed as how students judged the credibility of information. Although, some differences between Canadian and International students are observed, the overall outcome of the study shows these 18-year-old students, unlike younger seventh graders (Coiro, Coscarelli, Maykel, \& Forzani, 2015), are relatively cognizant of credibility and trustworthiness of the resources for academic information. Students use the same factors as previously reported studies (Kim \& Sin, 2016) to assess the credibility of information with one exception: Canadian students, more so than international students, rely on Google ranking (the top five results) for credibility judgement.

\section{Implications and Conclusions}

Differences were observed in the ISB of Canadian and international incoming university students, which may be attributed to different educational and cultural backgrounds (Liu \& Winn, 2009). Further research is needed to explore in more detail the factors that may contribute to these differences.

The biggest challenge in information literacy instructions, however, remains the reliance of the students on Google to access academic information. Ideally, secondary schools in all countries should include in their curricula an introduction to bibliographic databases to at least familiarize students with the concept of structured reliable information; there is a corresponding need for

International Association of School Librarianship https://www.iasl-online.org/ 
school libraries to be appropriately supported, staffed and able to acquire resources to provide appropriate IL instructions.

\section{Acknowledgement}

We would like to acknowledge the support of the Social Sciences and Humanities Research Council of Canada (SSHRC). 


\section{References}

American Association of School Librarians. (2017). Standards framework for the learner.

Retrieved from http://standards.aasl.org/wp-content/uploads/2017/11/AASL-Standards-

Framework-for-Learners-pamphlet.pdf

Beheshti, J. \& Large, A. (2013). The Future. In J. Beheshti \& A. Large (Eds.) The Information

Behavior of a New Generation: Children and Teens in the 21st Century. Toronto: Scarecrow Press, 237-242.

Bundy, A. (Ed.). (2004). Australian and New Zealand Information Literacy Framework:

Principles, Standards and Practice (2nd ed.). Adelaide: Australian and New Zealand Institute for Information Literacy.

Association of College and Research Libraries. (2015). Frameworkfor information literacy for higher education. Retrieved from http://www.ala.org/acrl/standards/ilframework

Armstrong, R. A. (2014). When to use the Bonferroni correction. Ophthalmic and Physiological Optics, 34(5), 502-508.

Cahoy, E. S. (2002). Will your students be ready for college? Connecting K-12 and college standards for information literacy. Knowledge Quest, 30(4), 12-15.

Chu, S. K. W., Reynolds, R. B., Tavares, N. J., Notari, M., \& Lee, C. W. Y. (2017). Twenty-First Century Skills Education in Hong Kong and Shenzhen, China: Inquiry Project-Based and Collaborative Teaching/Learning Supported by Wiki. In 21st Century Skills Development Through Inquiry-Based Learning (pp. 35-59). Springer, Singapore.

International Association of School Librarianship https://www.iasl-online.org/ 
Coiro, J., Coscarelli, C., Maykel, C., \& Forzani, E. (2015). Investigating criteria that seventh graders use to evaluate the quality of online information. Journal of Adolescent \& Adult Literacy, 59(3), 287-297.

Conde, J. M., Migueláñez, S. O., Molina, M. P., Abad, F. M., \& Riaza, B. G. (2011). Informational Literacy and Information and Communication Technologies Use by Secondary Education Students in Spain: A Descriptive Study. Contemporary Issues in Education Research, $4(4), 1-12$.

Detlor, B., Julien, H., Willson, R., \& Serenko, A. (2011). Learning outcomes of information literacy instruction at business schools. Journal of The American Society for Information Science and Technology, 62, 572-585.

Ellison, N. B., Steinfield, C., \& Lampe, C. (2007). The benefits of Facebook “friends:” Social capital and college students' use of online social network sites. Journal of computer-mediated communication, 12(4), 1143-1168.

Fitzgerald, M. A. (2004). Making the leap from high school to college. Knowledge Quest, 32(4), $19-24$.

Ginsca, A. L., Popescu, A., \& Lupu, M. (2015). Credibility in information retrieval. Foundations and Trends in Information Retrieval, 9(5), 355-475.

Gross, M., \& Latham, D. (2012). What's skill got to do with it?: Information literacy skills and self-views of ability among first-year college students. Journal of the Association for Information Science and Technology, 63(3), 574-583.

Hanushek, E. A., \& Luque, J. A. (2003). Efficiency and equity in schools around the world. Economics of education Review, 22(5), 481-502. 
Herring, J. E. (2011). Year 7 students, information literacy, and transfer: A Grounded Theory. School Library Research. American Library Association. Retrieved from: http://www.ala.org/aasl/sites/ala.org.aasl/files/content/aaslpubsandjournals/slr/vol14/SLR_Year7 $\underline{\text { Students_V14.pdf }}$

Hogan, N., \& Varnhagen, C. (2012). Critical Appraisal of Information on the Web in Practice: Undergraduate Students' Knowledge, Reported Use, and Behaviour. Canadian Journal of Learning and Technology, 38(1), n1.

Jung, I., \& Lee, Y. (2015). YouTube acceptance by university educators and students: a crosscultural perspective. Innovations in education and teaching international, 52(3), 243-253.

Kim, K. S., \& Sin, S. C. J. (2016). Use and evaluation of information from social media in the academic context: analysis of gap between students and librarians. The Journal of Academic Librarianship, 42(1), 74-82.

Kingsley, K., Galbraith, G. M., Herring, M., Stowers, E., Stewart, T., \& Kingsley, K. V. (2011). Why not just Google it? An assessment of information literacy skills in a biomedical science curriculum. BMC medical education, 11(1), 17.

Krippendorff, K. (1980). Reliability. John Wiley \& Sons, Inc.

Kovalik, C. L., Yutzey, S. D., \& Piazza, L. M. (2012). Assessing Change in High School Student Information Literacy Using the Tool for Real-Time Assessment of Information Literacy Skills. Contemporary Issues in Education Research, 5(3), 153-166.

Liu, G., \& Winn, D. (2009). Chinese graduate students and the Canadian academic library: A user study at the University of Windsor. The Journal of Academic Librarianship, 35(6), 565-573.

International Association of School Librarianship https://www.iasl-online.org/ 
Mackey, T.P. \& Jacobson, T.E. (2011). Reframing information literacy as a metaliteracy. College \& Research Libraries, 7(1), 62-78.

Mackey, T.P. \& Jacobson, T.E. (2014). Metaliteracy: Reinventing Information Literacy to Empower Learners. London: Facet.

Organisation for Economic Cooperation and Development. (2013). Skilled for Life?: Key findings from the Survey of Adult Skills. Retrieved from http://www.oecd.org/site/piaac/SkillsOutlook_2013_ebook.pdf

Pinto, M., Cordon, J. A., \& Gómez Díaz, R. (2010). Thirty years of information literacy (19772007) A terminological, conceptual and statistical analysis. Journal of librarianship and information science, 42(1), 3-19.

Project SAILS (Standardized Assessment of Information Literacy Skills). (2015). Welcome to the Project SAILS Information Literacy Assessment. Retrieved from https://www.projectsails.org

Saunders, L., Severyn, J., \& Caron, J. (2017). Don't they teach that in high school? Examining the high school to college information literacy gap. Library \& Information Science Research, 39(4), 276-283.

Serap Kurbanoglu, S., Akkoyunlu, B., \& Umay, A. (2006). Developing the information literacy self-efficacy scale. Journal of Documentation, 62(6), 730-743.

Sparks, J. R., Katz, I. R., \& Beile, P. M. (2016). Assessing Digital Information Literacy in Higher Education: A Review of Existing Frameworks and Assessments With Recommendations for Next-Generation Assessment. ETS Research Report Series, 2016(2), 1-33.

United Nations Educational, Scientific, and Cultural Organization. (2013). Global Media and Information Literacy Assessment Framework: Country readiness and competencies. Retrieved from http://unesdoc.unesco.org/images/0022/002246/224655e.pdf 
Table 1. Significant differences between Canadian and international students

\begin{tabular}{|l|l|l|l|l|l|}
\hline & $\begin{array}{l}\text { Canada } \\
\text { Mean }\end{array}$ & $\begin{array}{l}\text { International } \\
\text { Mean }\end{array}$ & $\mathrm{t}$ & $\mathrm{df}$ & Sig. (p) \\
\hline Sources & & & & & \\
\hline $\begin{array}{l}\text { Government/university } \\
\text { websites }\end{array}$ & 2.39 & 2.89 & 2.950 & 286 & 0.003 \\
\hline Social media & 2.04 & 2.49 & 2.773 & 285 & 0.006 \\
\hline Wiki & 2.82 & 3.29 & 2.762 & 286 & 0.006 \\
\hline Credibility & & & & & \\
\hline $\begin{array}{l}\text { Scholarly } \\
\text { books/journals }\end{array}$ & 4.45 & 3.93 & 3.829 & 214 & 0.001 \\
\hline Well-known websites & 2.63 & 3.02 & 2.521 & 219 & 0.012 \\
\hline Social media & 2.12 & 2.65 & 3.033 & 214 & 0.003 \\
\hline Blogs/forums & 2.34 & 3.02 & 4.044 & 110 & $<0.000$ \\
\hline Wiki & 2.85 & 3.43 & 3.298 & 224 & 0.001 \\
\hline Factors & 3.70 & 3.19 & 2.625 & 206 & 0.009 \\
\hline Top 5 Google results & 4.29 & 3.84 & 2.676 & 204 & 0.008 \\
\hline Quality of language & 4.27 & 3.58 & 3.729 & 72 & 0.001 \\
\hline Currency & 4.49 & 3.90 & 3.384 & 72 & 0.001 \\
\hline $\begin{array}{l}\text { Information matches } \\
\text { other sources }\end{array}$ & & & & & \\
\hline
\end{tabular}

Table 2. Information literacy instructions (Chi-square test)

\begin{tabular}{|l|l|l|l|}
\hline IL instructions & Canada $(\mathrm{n}=212)$ & International $(\mathrm{n}=76)$ & $\mathrm{p}$ \\
\hline Library instructions & $35.8 \%$ & $25 \%$ & 0.084 \\
\hline Citation management & $17.5 \%$ & $17.1 \%$ & 0.944 \\
\hline Database searching & $20.3 \%$ & $18.4 \%$ & 0.727 \\
\hline
\end{tabular}

International Association of School Librarianship https://www.iasl-online.org/ 
Table 3. Spearman's rho correlations $(\mathrm{p}<0.05)$

\begin{tabular}{|l|l|l|l|}
\hline Variables & Library instructions & Citation management & $\begin{array}{l}\text { Database } \\
\text { searching }\end{array}$ \\
\hline Sources & & & \\
\hline $\begin{array}{l}\text { Scholarly } \\
\text { books/journals }\end{array}$ & 0.201 & & 0.173 \\
\hline Wikis & & & -0.136 \\
\hline Credibility & & & \\
\hline $\begin{array}{l}\text { Scholarly } \\
\text { books/journals }\end{array}$ & 0.235 & & \\
\hline Experts & 0.181 & 0.179 & 0.171 \\
\hline Blogs/forums & -0.157 & & -0.143 \\
\hline Wikis & -0.158 & & \\
\hline Social media & & & -.199 \\
\hline Well-known websites & & & 0.230 \\
\hline Factors & & & 0.304 \\
\hline Currency & 0.175 & & -0.153 \\
\hline Tools & & & -0.181 \\
\hline Google Scholar & 0.161 & & \\
\hline JSTOR & 0.200 & & \\
\hline YouTube & & & \\
\hline Twitter & & & \\
\hline Library catalogue & & & \\
\hline ProQuest & & & \\
\hline EPSCO Host & & & \\
\hline
\end{tabular}




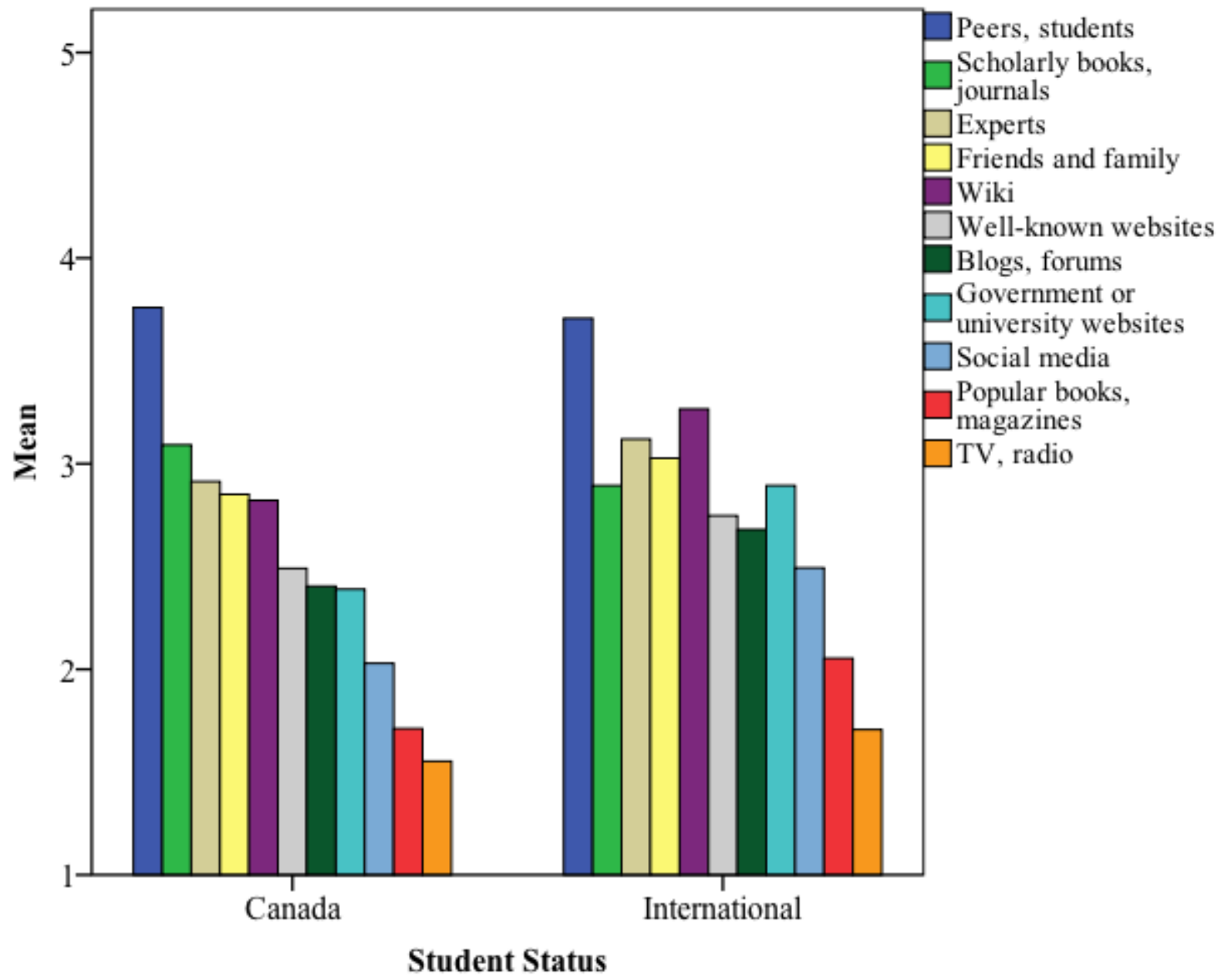

Figure 1. Information resources

International Association of School Librarianship https://www.iasl-online.org/ 


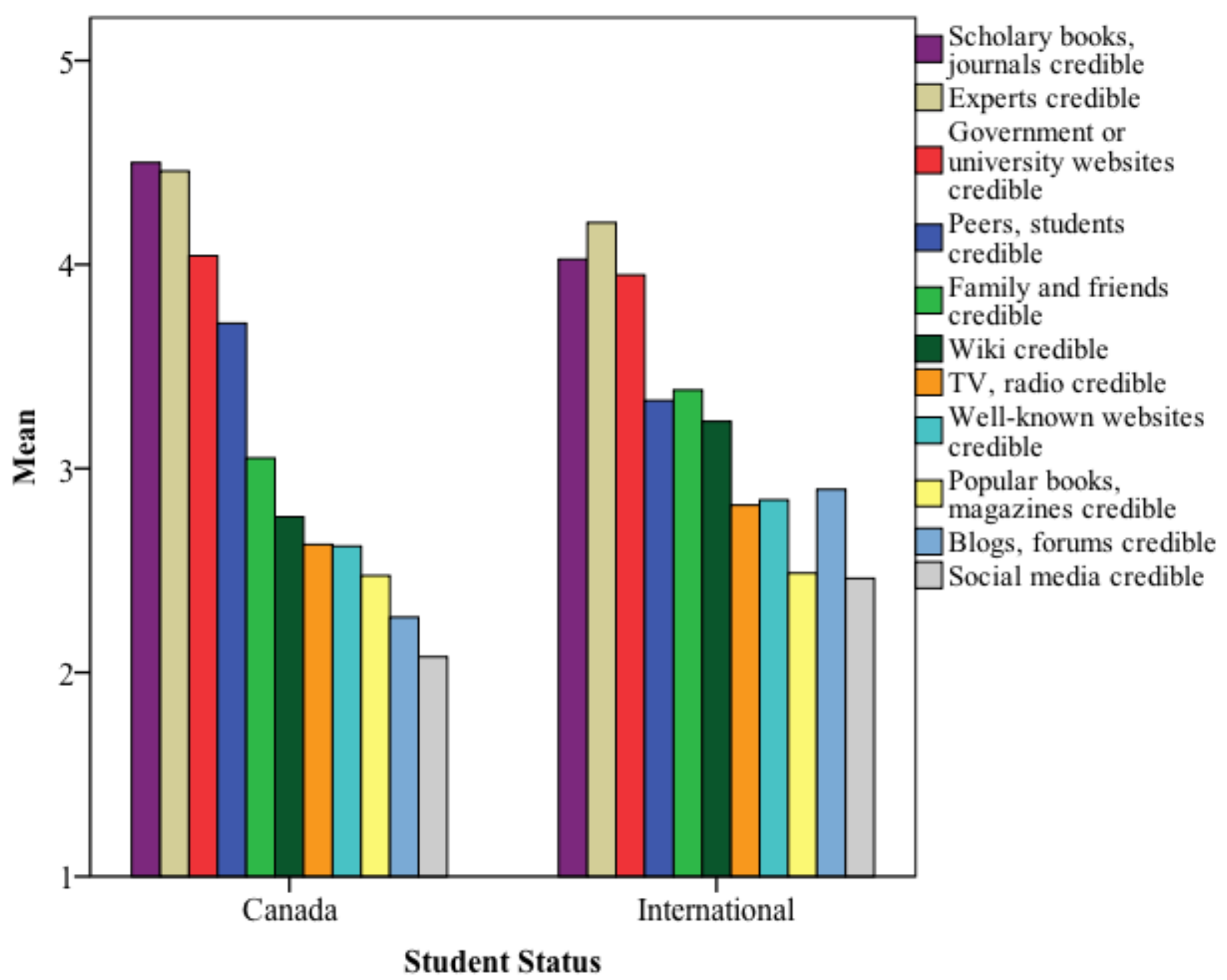

Figure 2. Credibility of information resources 


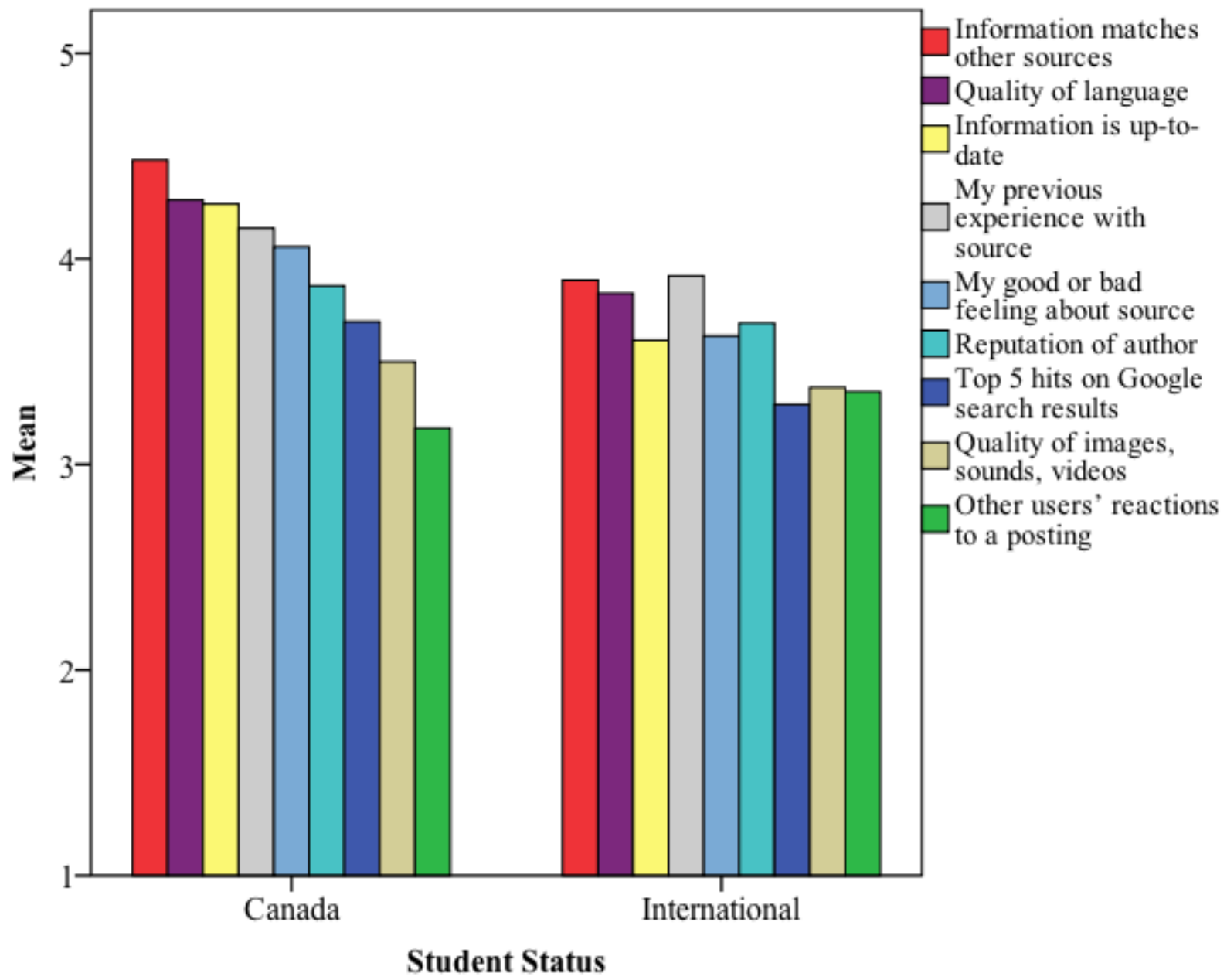

Figure 3. Factors considered in assessing credibility of information resources

International Association of School Librarianship https://www.iasl-online.org/ 


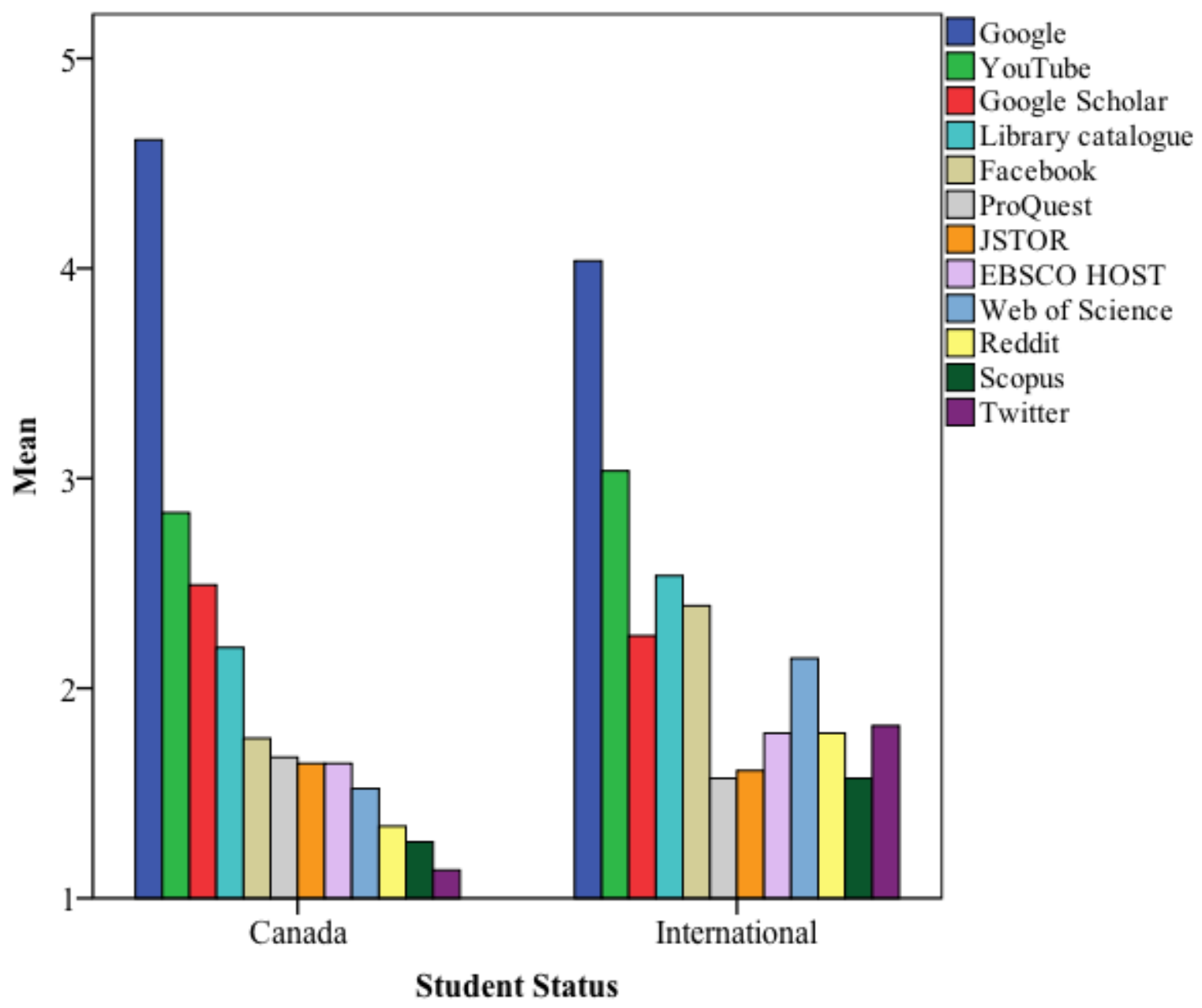

Figure 4. Tools to access academic information 